\title{
POTENTIAL ANTIBACTERIAL OF LEAVES AND FLOWERS BOUGENVILLEA (Bougenvilea glabra)
}

\author{
Priyanto Dwi Nugroho, Faisal Ismail, Hana Relita \\ Jurusan Analisa Farmasi dan Makanan, Politeknik Kesehatan Kemenkes Jakarta II, \\ J1. Raya Ragunan No.29C Pasar Minggu, DKI Jakarta, Kode Pos 12540 \\ E-mail: priyantodwinugroho@poltekkesjkt2.ac.id
}

\begin{abstract}
High incidence of antibiotics resistant bacteria spurred researchers to obtain alternative antibacterial compounds. One source of potential antibacterial compounds i.e plants. Bougainvillea (Bougenvillea glabra) has been believed by the people of Indonesia to have medicinal properties, but its potential as an antibacterial has never been studied in Indonesia. The aims of this study were to determine the bioactive compounds ethanol extract of leaves and flowers of B. glabra as well as the minimum concentration of extract capable of inhibiting and killing bacteria growth.Minimum Inhibition Concentration (MIC) was done used microdilution method and Minimum Bactericidal Concentration (MBC) agar plate method. Ethanol extract of leaves and flowers of $B$. glabra possess antibacterial activity against pathogenic bacteria; Bacillus sp., $S$. aureus, Salmonella sp., E. coli, $P$. aeruginosa and $K$. pneumoniae. Salmonella, Bacillus sp., and $S$. aureus growth is most vulnerable ( $\mathrm{p}<0.05)$. The antibacterial activity of leaf and flower extracts was not significantly different ( $p>0.05)$ against all test bacteria. Antibacterial potency of leaves and flowers B. glabra suspected of flavonoids, tannins, terpenoids and alkaloids.
\end{abstract}

Keywords: antibacterial, bougainvillea, ethanol extract

\section{POTENSI ANTIBAKTERI DAUN DAN BUNGA BUGENVIL (Bougenvilea glabra)}

\begin{abstract}
ABSTRAK
Angka kejadian bakteri resisten antibiotik yang tinggi memacu peneliti untuk memperoleh senyawa antibakteri alternatif.Salah satu sumber senyawa antibakteri yang berpotensi yakni tumbuhan.Tanaman bugenvil (Bougenvillea glabra)merupakan salah satu jenis tumbuhan yang diyakini oleh masyarakat Indonesia memiliki khasiat obat, namun potensinya sebagai antibakteri belum pernah diteliti di Indonesia.Penelitian dilakukan untuk mengetahui kandungan senyawa bioaktif ekstrak etanol daun dan bunga B. glabra serta konsentrasi minimum ekstrak yang mampu menghambat dan membunuh pertumbuhan bakteri.Konsentrasi Hambat Minimum (KHM) menggunakan metode mikrodilusi dan Konsentrasi Bakterisidal Minimum (KBM) menggunakan metode cawan agar. Ekstrak etanol daun dan bunga B. glabra memiliki aktivitas antibakteri terhadap seluruh bakteri uji; Bacillus sp., S. aureus, Salmonella sp., E. coli.,P. aeruginosa, dan K. pneumoniae. Menariknya pertumbuhan P. aeruginosaresistenklorampenikol, ternyata rentan terhadap ekstrak etanol daun dan bunga B. glabra.Bakteri Salmonella, Bacillus sp., dan S. aureus pertumbuhannya paling rentan terhadap ekstrak etanol daun dan bunga B. glabra $(\mathrm{p}<0.05)$.Daya antibakteri ekstrak daun dan bunga berbeda tidak nyata $(p>0.05)$ terhadap seluruh bakteri uji.Potensi antibakteri daun dan bunga bugenvil diduga dari kandungan flavonoid, tanin, terpenoid, dan alkaloid.
\end{abstract}

Kata kunci: antibakteri, bugenvil, ekstrak etanol 


\section{PENDAHULUAN}

Penyakit menular atau infeksi bakteri patogen termasuk penyebab kematian tertinggi di beberapa negara berkembang termasuk di Indonesia (1).Pengobatan untuk penyakit infeksi melalui pemberian antibiotik.Antibiotik merupakan senyawa kimia yang bersifat membunuh dan menghambat pertumbuhan mikrob patogen (2).Penggunaan dan pemilihan antibiotik yang tidak tepat menyebabkan bakteri patogen menjadi resisten terhadap antibiotik.Hasil surveilens resistensi antibiotik menunjukkan bahwa 50\% bakteri patogen telah resisten terhadap antibiotik yang diberikan pada tahap awal pengobatan penyakit (3).

Angka kejadian resistensi terhadap antibiotik yang cukup tinggi mendorong penelitian untuk memperoleh senyawa antibakteri alternatif selain antibiotik.Salah satu sumber senyawa antibakteri yang berpotensi yakni terdapat di dalam bahan alam seperti tumbuhan.Bougenvillea glabra yang lebih dikenal dengan tanaman bugenvil merupakan salah satu tanaman yang banyak ditanam di rumah sebagai tanaman hias karena warna bunganya yang menarik dan banyaknya bunga yang dihasilkan pada saat mekar. Bunga dan daun Bougenvillea glabra juga diyakini oleh masyarakat Indonesia memiliki khasiat untuk menyembuhkan penyakit, antara lain: hepatitis, bisul, keputihan, dan mengurangi nyeri haid (4).

Ekstrak tanaman Bougenvillea glabra dilaporkan memiliki aktivitas anti inflamasi, anti hiperglikemik, dan bersifat insektisidal (5).Senyawa bioaktif ekstrak daun dan bunga Bougenvillea glabra dilaporkan memiliki aktivitas anti bakteri (6-8). Penelitian mengenai kandungan senyawa bioaktif ekstrak daun dan bunga Bougenvillea glabra sebagai anti bakteri belum pernah dilakukan di Indonesia, oleh karena itu penelitian yang akan dilakukan ini sangat bermanfaat untuk memperoleh informasi kandungan senyawa bioaktif dari ekstrak daun dan bunga Bougenvillea glabra serta potensinya sebagai anti bakteri.

\section{METODE PENELITIAN}

Pemilihan sampel daun dan bunga bugenvil ditentukan berdasarkan metode purposive sampling.Daun yang digunakan adalah daun Bougenvillea glabra yang terletak pada 2-3 daun dari pucuk tanaman, sedangkan untuk bunga yang digunakan adalah semua bunga yang terdapat pada tanaman.Sampel untuk penelitian diperoleh dari Balai Penelitian Tanaman Rempah dan Obat (Balitro) Bogor.

Ekstrak dibuat sebagai bahan penapisan senyawa bioaktif dan uji aktivitas anti bakteri.Ekstrak dibuat menggunakan metode maserasi dengan pelarut etanol 95\%.Serbuk kering daun dan bunga Bougenvillea glabra masing-masing sebanyak 500 gr direndam dengan Etanol 96\%. Proses maserasi ini dilakukan selama dua minggu pada suhu ruang dan terhindar dari cahaya matahari. Semua maserat dikumpulkan dan disaring menggunakan kertas saring Whatman no. 1 (8).

Filtrat kemudian dievaporasi menggunakan evaporator vakum dengan suhu di bawah $50{ }^{\circ} \mathrm{C}$ hingga diperoleh ekstrak kental.Rendemen ekstrak kental yang diperoleh ditimbang dan dicatat. Ekstrak kental disimpan pada suhu $4-8{ }^{\circ} \mathrm{C}$. Ekstrak kental selanjutnya digunakan untuk penapisan senyawa bioaktif dan uji aktivitas anti bakteri.

Uji penapisan senyawa bioaktif dilakukan dengan tiga kali ulangan untuk setiap uji (9). Penapisan senyawa bioaktif/fitokimia terdiri dari: steroid, terpenoid, tannin, flavonoid, alkaloid, saponin, fenol, glikosida, dan phlobatannin. 
Aktivitas anti bakteri ekstrak daun dan bunga Bougenvillea glabra dilakukan menggunakan Konsentrasi Hambatan Minimum (KHM) dengan metode mikrodilusi (10), dan Konsentrasi Bakterisidal Minimum (KBM) menggunakan metode agar cawan (11). Bakteri uji yang digunakan merupakan koleksi laboratorium Mikrobiologi Jurusan Analisa Farmasi dan Makanan, yang terdiri dari: $S$. aureus, Bacillus, P. aeruginosa, Salmonella, E. coli, dan K. pneumoniae dengan konsentrasi $1 \times 10^{8}$ $\mathrm{CFU} \mathrm{mL}^{-1}$. Media yang digunakan yakni agar Mueller Hinton (MH) (Merck) dan kaldu Brain Heart Infusion (BHI) (Merck).

Penentuan konsentrasi hambatan minimum untuk mengetahui konsentrasi terendah dari suatu senyawa yang mampu menghambat pertumbuhan bakteri uji. Ekstrak diencerkan menjadi konsentrasi 2000 $\mu \mathrm{g} / \mu \mathrm{L}$ hingga $1.0 \mu \mathrm{g} / \mu \mathrm{L}$. Masing-masing pengenceran sebanyak $100 \mu \mathrm{L}$ dimasukkan ke dalam microtube 1.5 mLyang telah berisi $100 \mu \mathrm{L}$ bakteri uji dan $10 \mu \mathrm{L}$ Tetrazolium Chloride $0.5 \%$. Seluruh biakan diinkubasi selama 18-24 jam pada suhu $37^{\circ} \mathrm{C}$.

Pertumbuhan bakteri berupa kekeruhan dan warna merah diamati pada seluruh pengenceran.Pengenceran terendah yang tidak terdapat pertumbuhan bakteri diamati dan dicatat serta dinyatakan sebagai nilai KHM.

Jumlah bakteri yang sangat sedikit akan tidak tampak pertumbuhannya pada uji KHM, sehingga pengenceran yang tidak memperlihatkan pertumbuhan bakteri perlu di inokulasi pada media agar untuk mengetahui pertumbuhan bakteri secara lebih jelas. Pengujian tersebut dinamakan KBM. Pengenceran pada uji KHM yang tidak memperlihatkan pertumbuhan bakteri dipipet sebanyak $100 \mu \mathrm{L}$ dan diinokulasikan ke dalam agar $\mathrm{MH}$ menggunakan metode gores (streak). Seluruh biakan diinkubasi selama
18-24 jam pada suhu $37{ }^{\circ} \mathrm{C}$. Koloni yang tumbuh pada setiap cawan pengenceran diamati serta dicatat. Pengenceran terendah yang tidak terdapat koloni bakteri dinyatakan sebagai nilai KBM.Seluruh data aktivitas anti bakteri dari ekstrak daun dan bunga Bougenvillea glabra dianalisis secara statistik menggunakan piranti lunak minitab17. Analisis ANOVA satu arah digunakan untuk mengetahui perbedaan nilai rata-rata konsentrasi hambat minimum dan konsentrasi bakterisidal minimum antara kelompok bakteri.Uji $\mathrm{T}$ tidak berpasangan digunakan untuk mengetahui perbedaan nilai rata-rata konsentrasi hambat minimum dan konsentrasi bakterisidal minimum antara ekstrak etanol daun dengan ekstrak etanol bunga $B$. glabra.

\section{HASIL DAN PEMBAHASAN}

Hasil pemekatan ekstrak menunjukkan bahwa rendeman ekstrak daun sebesar 17.24\%, dan rendeman ekstrak bunga sebesar $6.92 \%$ (tabel $1)$.

Tabel 1 Rendeman Ekstrak Daun dan Bunga Bougenvillea Glabra

\begin{tabular}{lccc}
\hline $\begin{array}{l}\text { Jenis } \\
\text { ekstrak }\end{array}$ & $\begin{array}{c}\text { Bobot } \\
\text { simplisia } \\
(\text { gr })\end{array}$ & $\begin{array}{c}\text { Bobot } \\
\text { ekstrak } \\
(\mathrm{gr})\end{array}$ & $\begin{array}{c}\text { Rendeman } \\
(\%)\end{array}$ \\
\hline $\begin{array}{l}\text { Ekstrak } \\
\text { daun }\end{array}$ & 500 & 86.2 & 17.24 \\
$\begin{array}{l}\text { Ekstrak } \\
\text { bunga }\end{array}$ & 500 & 34.6 & 6.92 \\
\hline
\end{tabular}

Hasil penapisan senyawa bioaktiv ekstrak etanol daun dan bunga B. glabra menunjukkan adanya perbedaan kandungan senyawa bioaktif diantara kedua bagian tanaman tersebut (Tabel 3). Daun bugenvil yang diteliti mengandung senyawa bioaktif alkaloid dan saponin' hal ini berbeda dengan 
penelitian sebelumnya yang melaporkan daun B. glabra tidak mengandung alkaloid dan saponin (12,13). Kandungan senyawa bioaktif pada bunga juga berbeda dengan penelitian terdahulu $(14,15)$. Hasil yang berbeda diduga karena analisis kandungan senyawa bioaktif bersifat kualitatif berdasarkan perubahan warna yang diamati secara visual.

Ekstrak etanol bunga B. glabra memiliki aktivitas penghambatan pertumbuhan dan bakterisidal yang lebih kuat terhadap bakteri $E$. coli dan $K$. pneumoniae dibandingkan dengan ekstrak etanol daun $B$. glabra. Pertumbuhan bakteri Salmonella, Bacillus, dan $S$. aureus paling rentan terhadap ekstrak daun dan bunga bugenvil (Tabel 2).

Tabel 2 KHM \& KBM $(\mu \mathrm{g} / \mu \mathrm{L})$ Ekstrak Etanol Daun dan Bunga B. glabra

\begin{tabular}{lcccc}
\hline \multirow{2}{*}{ Jenis bakteri } & \multicolumn{2}{c}{ KHM } & \multicolumn{2}{c}{ KBM } \\
\cline { 2 - 5 } & ED & EB & ED & EB \\
\hline E. coli & $835^{\mathrm{a}}$ & $500^{\mathrm{a}}$ & $1670^{\mathrm{a}}$ & $1000^{\mathrm{a}}$ \\
K. pneumoniae & $835^{\mathrm{a}}$ & $500^{\mathrm{a}}$ & $1670^{\mathrm{a}}$ & $1000^{\mathrm{a}}$ \\
P. aeruginosa & $209^{\mathrm{b}}$ & $1000^{\mathrm{b}}$ & $418^{\mathrm{b}}$ & $2000^{\mathrm{b}}$ \\
Salmonella sp. & $3^{\mathrm{c}}$ & $62.5^{\mathrm{c}}$ & $6^{\mathrm{c}}$ & $125^{\mathrm{c}}$ \\
Bacillus sp. & $1^{\mathrm{c}}$ & $15^{\mathrm{d}}$ & $2^{\mathrm{c}}$ & $30^{\mathrm{d}}$ \\
S. aureus & $13^{\mathrm{d}}$ & $250^{\mathrm{e}}$ & $26^{\mathrm{d}}$ & $500^{\mathrm{e}}$ \\
\hline
\end{tabular}

ED: ekstrak daun; EB: ekstrak bunga

Angka pada tabel dengan huruf yang berbeda menunjukan perbedaan signifikan $(\mathrm{p}<0.05)$

Hal yang menarik pada penelitian ini bahwa aktivitas antibakteri ekstrak etanol bunga $B$. glabra lebih kuat dari penelitian sebelumnya (16). Selain itu ekstrak etanol daun dan bunga $B$. glabra pada penelitian ini memiliki aktivitas antibakteri yang bersifat spektrum luas, yakni mampu menghambat pertumbuhan bakteri Gram positif dan Gram negatif; hal ini berbeda dengan hasil penelitian terdahulu yang menunjukkan aktivitas ekstrak etanol bunga $B$. glabra bersifat spektrum sempit; hanya aktif terhadap bakteri Gram negatif $E$. coli dan $P$. aeruginosa (17).

Aktivitas penghambatan pertumbuhan dan daya bakterisidal antara daun dengan bunga $B$. glabra terhadap keenam bakteri uji berbeda tidak nyata $(\mathrm{p}>0.05)$. Daya antibakteri daun dan bunga yang sama kuat diduga karena hanya terdapat sedikit perbedaan kandungan senyawa bioaktif antara daun dan bunga B. glabra (Tabel 3).

Daya antibakteri dari tanaman B. glabra diduga kuat berasal dari senyawa bioaktif

Tabel 3 Kandungan senyawa bioaktif daun dan bunga $B$. glabra

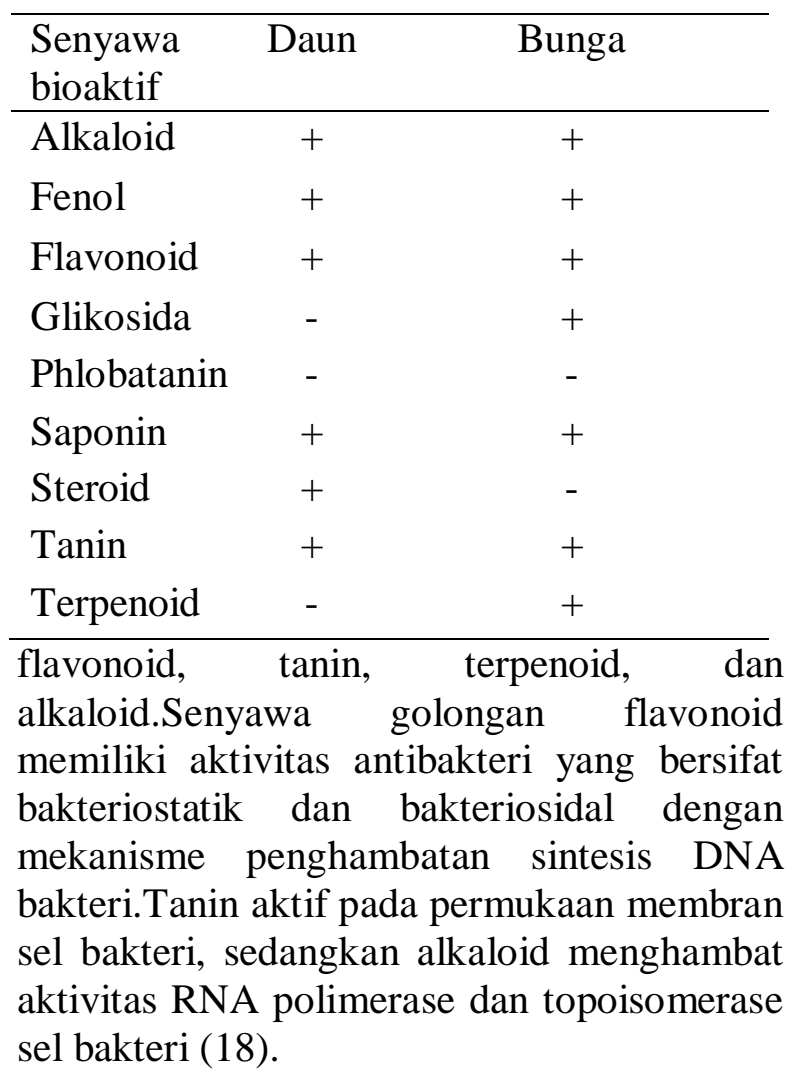




\section{KESIMPULAN DAN SARAN}

Daun B. glabra mengandung senyawa bioaktif alkaloid, fenol, flavonoid, glikosida, saponin, steroid, dan tanin.Alkaloid, fenol, flavonoid, saponin, tanin, dan terpenoid terdapat di dalam bunga B. glabra. Ekstrak etanol daun dan bunga Bougenvillea glabra memiliki aktivitas antibakteri terhadap bakteri patogen Bacillus, S. aureus, Salmonella, E. coli.,P. aeruginosa, dan $K$. pneumoniae.

Ekstrak etanol daun dan bunga $B$. glabra memberikan pengaruh sangat nyata terhadap penghambatan pertumbuhan Bacillus, Salmonella, dan S. aureus. Daya antibakteri ekstrak etanol daun dan bunga berbeda tidak nyata.

Daun dan bunga bugenvil memiliki potensi sebagai antibakteri yang layak dikaji lebih lanjut sebagai sumber antibakteri yang mampu menghambat bakteri resisten antibiotik. Fraksinasi senyawa bioaktif lebih lanjut menggunakan berbagai pelarut dan isolasi senyawa tunggal yang paling aktif menghambat pertumbuhan dan membunuh bakteri patogen perlu dilakukan untuk memperoleh senyawa aktif yang dapat disintesis sebagai antibiotik.

\section{DAFTAR PUSTAKA}

1. Global Burden of Disease Study 2013 Mortality and Causes of Death Collaborators. 2015. Global, regional, and national age sex specific all-cause and cause-spesific mortality for 240 causes of death, 1990-2013: a systematic analysis for the Global burden of Disease Study 2013. Lancet. 2015; 385(9963):117-171.

2. Madigan MT, Martinko JM, Stahl DA, Clark DP. Brock Biology of
Microorganisms14th ed. New Jersey (US):Prentice Hall. 2015

3. [WHO] World Health Organization. 2014. Antimicrobial resistance: global report on surveillance. Geneva (SUI).

4. Tukiran, Suyatno, Hidayati N. Phytochemical screening on several extracts of Bougenvillea glabra, Hibiscus rosa-sinensis

GraptophylumpictumGriff. Prosiding Seminar Nasional Kimia. 2014;B235245.

5. Sahu N, Saxena J. Phytochemical analysis of Bougenvillea glabra Choisy by FTIR and uv-vis spectroscopic analysis. Int J Pharm Sci Rev Res. 2013; 21(1):196-198.

6. Gupta V, George M, Joseph L, Singhal M, Singh HP. Evaluation of antibacterial activity of Bougenvillea glabra 'snow white' and Bougenvillea glabra 'choisy'. J ChemPharmaceutic Res. 2009; 1(1): 233-237.

7. Swamy K, Sudipta KM, Lokesh P, Neeld MA, Rashmi W, Bhaumik H, Darshil H, Vijay R, Kashyap SSN.. Phytochemical screening and in vitro antimicrobial activity of Bougenvilleaspectabilisflower extracts. Int J Phytomed. 2012;4(3): 375379.

8. Enciso-Diaz OJ, Mendez-Guiteres A, De Jesus LH, Sharma A, Villareal ML, Taketa AC. Antibacterial activity of Bougenvillea glabra, Eucalyptus globus, Gnaphaliumattenuatum, and propolis collected in Mexico. Pharmacol Pharm. 2012;3: 433-438.

9. Harborne AJ. Phytochemical Methods A Guide to Modern Techniques of Plant Analysis. Springer. 1998.

10. Andrews JM. Determination of minimum inhibitory concentrations. J AntimicrobChemother. 2001; 48(suppl 1): 5-16. 
11. Yilmaz MT. Minimum inhibitory and minimum bactericidal concentrations of boron compounds against several bacterial strains. Turk J Med Sci.2012; 42(2): 1423-1429.

12. Rani JM, Chandramohan G, Rengnathan R. Antioxidant activity, preliminary phytochemical investigation and GC-MS study of Bougenvillea glabraChoisy leaves. Int $\mathbf{J}$ Pharm Pharmaseutic Sci. 2012; 4(2):12-16.

13. Mariajancyrani J, Chandramohan G, Beevi MF, Elayaraja A. Preliminary phytochemical investigation and antioxidant activity of Bougenvillea glabra Choisy leaves. SchAcad J Biosci. 2013; 1(3): 72-75.

14. Eslavath R, Harikrishna V, Kosuru N, Venkateshwarlu G, Sabat M, Kanakaiah K. Phytochemical screening and TLC, uv-vissprectophotometer study of Bougenvillea glabra. Asian J Pharm Ana. 2013; 3(3): 83-85.
15. Sahu N, Saxena J. A comparative phytochemical analysis of Bougenvillea glabra Choisy and 'califorina gold'. Int $\mathbf{J}$ Pharm Bio Sci. 2012; 3(3): 247-250.

16. Bungihan ME, Matias CA. Determination of the antioxidant, phytochemical and antibacterial profiles of flowers from selected ornamental plants in Nueva Vizcaya, Philippines. J AgriculSci Tech. 2013; B3: 833-841.

17. Perales YJ, Leysa M. Phytochemical screening and antibacterial activity of Bougenvillea glabra plant extract as potensial sources of antibacterial and resistance-modifying agents. Int Confer Life Sci Engineer. 2012; 45(25): 121125.

18. Panigrahi S, Mahaprata S. Evaluation of antibacterial activity of Pongamia pinnata L., Curcuma longa L. and Menthaarvenis L. against Staphylococcus aureus. Int J Chemtech Res.2016;9(2):205-212. 